\title{
THE MODERATING IMPACT OF FIRM SIZE ON THE RELATIONSHIP BETWEEN WORKING CAPITAL MANAGEMENT AND PROFITABILITY
}

\author{
Ilhan Dalci, Cem Tanova, Hasan Ozyapici, Murad A. Bein*
}

\begin{abstract}
This study investigates whether firm size moderates the relationship between cash conversion cycle and profitability over 8-year period for 285 German non-financial firms. The moderated regression results reveal that the relationship between cash conversion cycle and profitability is moderated by firm size. As the firm size gets smaller and the cash conversion cycle gets longer, the returns on assets decreases. When the firm size gets bigger and the cash conversion cycle gets longer, on the other hand, the returns on assets increases. In this context, reducing the length of cash conversion cycle has a positive impact on profitability for only small and medium-sized firms. Accordingly, this study concludes that small and also medium-sized firms, contrary to big firms, should reduce the length of cash conversion cycle in order to increase profitability.
\end{abstract}

Keywords: cash conversion cycle, firm size, small firms, profitability, working capital management JEL Classification: M10, M41

\section{Introduction}

An effective Working Capital Management (WCM) system has been an important tool for companies in order to maximize profitability and gain a competitive advantage (Ruback and Sesia, 2003). Limitations of traditional working capital measures have led to the emergence of dynamic measures which analyse a firm's continuing liquidity (Hager, 1976; Richards and Laughlin, 1980; Emery, 1984). In this regard, the Cash Conversion Cycle (CCC) which is a dynamic measure has been introduced by Gitman (1974) as a powerful approach to WCM (Richards and Laughlin, 1980; Jose et al., 1996; Ebben and Johnson, 2011). The CCC refers to the difference concerning the situation when a firm pays for its trade payables and collects trade receivables emerging from sale of goods to customers (Deloof, 2003). In other words, the CCC is a dynamic measure of time between the moment when a company collects its accounts receivable due from sales of inventories and when it pays for its accounts payable resulting from purchases (Richards and Laughlin, 1980; Deloof, 2003). Attempting to maintain a positive working capital may avoid running out of stock of inventories. However,

* Ilhan Dalci, Faculty of Business and Economics, Eastern Mediterranean University, Famagusta,

North Cyprus via Mersin 10, Turkey (ilhan.dalci@emu.edu.tr);

Cem Tanova, Faculty of Business and Economics, Eastern Mediterranean University, Famagusta,

North Cyprus via Mersin 10, Turkey (cem.tanova@emu.edu.tr);

Hasan Ozyapici, Faculty of Business and Economics, Eastern Mediterranean University, Famagusta,

North Cyprus via Mersin 10, Turkey (hasan.ozyapici@emu.edu.tr);

Murad A. Bein, Faculty of Economics and Administrative Sciences, Cyprus International University, Lefkosa, North Cyprus via Mersin 10, Turkey (mbein@ciu.edu.tr). 
an opportunity costs associated with having positive working capital may exist and result in a reduction in profitability (Singhania et al., 2014). Therefore, an effective WCM aims at avoiding excessive investment in current assets, while maintaining a company's ability to find a healthy balance between liquidity and profitability (Filbeck et al., 2007).

There have been a number of studies investigating the relationship between CCC and firm performance (e.g. Smith, 1987; Kamath, 1989; Jose et al., 1996; Wang, 2002; Deloof, 2003; Padachi, 2006; Gill et al., 2010; Aregbeyen, 2013). Most of these studies have been carried out in the US and European countries. To the best of our knowledge, however, there is no study exploring the relationship between CCC and profitability in Germany. Lind et al. (2012) assert that profitability problems and increased competition have necessitated the need for improving WCM for German companies. Accordingly, the results of this study are expected to address this issue. Additionally, Jose et al. (1996) assert that size differences should be taken into account when dealing with the relationship between CCC and profitability in order to see whether the observed relationship is affected by size. The previous studies which have investigated WCM-profitability relationship have focussed on total sample of firms (e.g. Jose et al., 1996), large firms (e.g. Shin and Soenen, 1998), small firms (e.g. Ebben and Johnson, 2011), and/or small and mediumsized firms (e.g. Yazdanfar and Öhman, 2014). The literature review reveals only one study (Nobanee et al., 2011) which has investigated WCM-profitability relationship by making comparisons among small, medium-sized, and large firms in Japan. The authors have found that the CCC influences profitability in the same directions for the firms of all sizes. However, this finding may be unique for the Japanese environment which has the "keiretsu" system as a dominant characteristic of the Japanese economy. The "keiretsu" may eliminate the effect of "size" factor on the relationship between CCC and profitability because this system creates a web of interlocking relationships and may lead to different considerations between buyer and supplier firms. Accordingly, we would expect that the inverse impact of CCC on profitability should be stronger for small firms because cost of external financing is higher for these firms (see Moss and Stine, 1993). In order to explore this issue, the current study investigates whether firm size has a moderating impact on the relationship between WCM and profitability. In this regard, this study is unique in the sense that it is the first attempt to investigate the moderating role of leverage, which is the measure of size, on the relationship between CCC and profitability.

The paper progresses as follows: In the Section 2, the literature review and hypotheses are outlined. Then, the research methodology is presented in Section 3. This is followed by Section 4 the results of the study. The conclusions and implications are then outlined in the Section 5.

\section{Literature Review and Hypotheses}

\subsection{Impact of CCC on profitability}

Prior studies have demonstrated that WCM strongly influences profitability (e.g. Wang, 2002; Deloof, 2003; Eljelly, 2004). The previous studies which have investigated 
the WCM-profitability relationship have generally found an inverse relationship between the two measures (e.g. Long et al., 1993; Shin and Soenen, 1998; Eljelly, 2004; Hutchison et al., 2007). For example, Jose et al. (1996) investigate the impact of CCC on profitability for 2,718 Compustat firms operating in seven industries in the US over a 20-year period. The result of that study demonstrates that the shorter the CCC the higher the profitability for some industries such as manufacturing, service, and retail/wholesale. Another study carried out in the US by Shin and Soenen (1998) reveals an inverse relationship between Net Trading Cycle (NTC), which is closely related to CCC, and profitability. Kamath (1989) finds that the NTC negatively influences firm performance for the Retail Grocery industry in general. In Japan and Taiwan, Wang (2002) explores the relationship among WCM, profitability, and corporate value for 1934 firms over an 11-year period. The authors come up with an inverse relationship between CCC and profitability. In Belgium, Deloof (2003) analyzes the impact of WCM on profitability for a sample of 1,009 large non-financial firms for the 1992-1996 period. The results of that study reveal a significant negative relationship between the two measures. Eljelly (2004) investigates the relationship between profitability and liquidity in Saudi Arabia. The results show an inverse relationship between profitability and liquidity. In another study, Padachi (2006) also finds that WCM has an inverse impact on profitability of small Mauritian manufacturing firms. In Spain, Garcia-Teurel and Martinez-Solano (2007) find similar results showing shorter CCC has a positive impact on ROA for small firms. By focussing on companies listed on Vietnam Stock Exchange, Dong and $\mathrm{Su}$ (2010) add evidence to a strong negative impact of CCC on profitability. In Japan, Nobanee et al. (2011) explore the impact of CCC on profitability measured by Return on Investment (ROI) for the period from 1990 to 2004. In that study, except for consumer goods and services companies, a strong inverse relation is found between the CCC and ROI. In Sweden, Yazdanfar and Öhman (2014) investigate the relationship between CCC and profitability for small and medium-sized companies and find a negative relationship between the two measures. Singhania et al. (2014) also report a negative CCC-profitability trade-off for manufacturing companies listed on the BSE-500 index of the Bombay Stock Exchange in India.

In contrast to the above studies, there are number of studies (e.g. Lyroudi and Lazaridis, 2000; Sharma and Kumar, 2011) which report that WCM positively influences profitability. For example, Lyroudi and Lazaridis (2000) examine the food industry in Greece and find that CCC has a positive influence on ROA. The other study conducted in the US by Gill et al. (2010) also reveals a positive influence of CCC on profitability. Similarly, Sharma and Kumar (2011) find that CCC positively influences profitability of non-financial firms in India.

On the other hand, two recent studies (Baños-Caballero et al., 2014; Mun and Jang, 2015) find a concaved U-shaped relationship between the measures of working capital (NTC and Working Capital Rate) and firm performance. Ba nos-Caballero et al. (2014) analyse the impact of NTC on corporate performance for non-financial companies in the UK. That study is the first attempt to find an inverted U-shaped relationship between WCM and profitability. In the US, Mun and Jang (2015) analyse the impact of WCM on ROA 
for restaurant firms. The authors also examine the moderating impact of firms' cash levels on the relationship between working capital and profitability. In line with Ba nos-Caballero et al. (2014), these authors also find a strong U-shaped working capital-profitability relationship. This study also demonstrates that a firm's cash level is an important factor for efficient WCM.

Consequently, despite the fact that the results of previous studies concerning the CCC-profitability relationship are inconclusive, more evidence supports the existence of a negative relationship. Thus, the following hypothesis has been formulated:

H1: There is a negative relationship between CCC and profitability of German nonfinancial firms.

\subsection{Moderating impact of firm size on the relationship between CCC and profitability}

Long CCC leads to an increase in inventories and receivables which causes working capital to increase (Richards and Laughlin, 1980; Ebben and Johnson, 2011). In this case, accruals/ payables, interest-bearing debt, and equity are used to fund receivables and inventories. Accordingly, expensive external sources reduce profitability due to high interest costs and tied-up funds which would otherwise be invested in profitable areas. It is important to emphasize that small firms may differ from large firms in many dimensions of performance (Storey, 1989). Previous studies (e.g. Stiglitz and Weiss, 1981; Rajan and Zingales, 1995; Berger and Udell, 1995; Shane and Cable, 2002; Cassar, 2004) have revealed that bigger firms have better opportunities to get external financing and they are not as financially constraint as small firms. This means that impact of CCC on profitability might be different for firms with different sizes. Parallel to this, Jose et al. (1996) note that size differences should be considered, while dealing with CCC-profitability relationship in order to see whether the observed relationship is affected by size. This means that, the impact of CCC on profitability is expected to be influenced by firm size. The reason that some research shows conflicting results on the relationship between CCC and profitability may be due to the impact of firm size. Based on these considerations, we expect that the CCC-profitability relationship may be moderated by firm size. Thus, the following hypothesis has been proposed:

H2: Firm size has a moderating impact on the relationship between CCC and profitability of German non-financial firms.

Based on the above theoretical framework and the hypotheses, the following conceptual model can be proposed: 


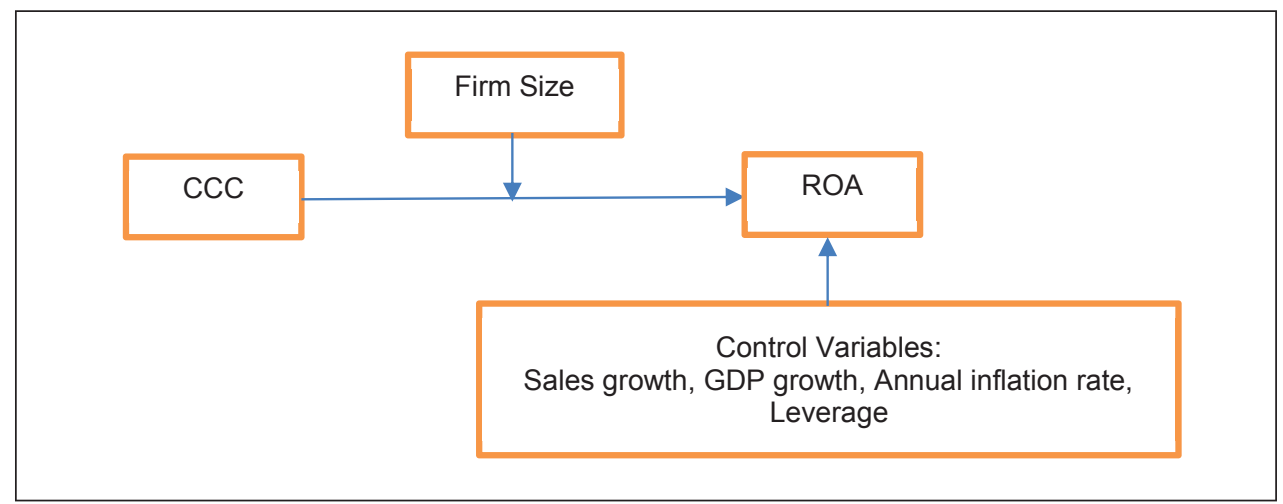

Source: Authors.

\section{Research Methodology}

\subsection{Sample and data collection}

This study uses German non-financial firms' data for the years 2006-2013. The data set including mainly statement of financial position and income statement is solicited from the DataStream. Some firms with missing data are eliminated from the sample. We consider all German non-financial firms that are listed in stock exchanges. However, since there were many firms with missing data and extreme value (perhaps due to firm specific structure changes and financial crisis), we had to eliminate some firms with such problems. Beside, we make use of strong balanced panel data that requires the presence of all observation. Accordingly, 285 firms are left with 2,280 observations due to these eliminations. Our sample period started 2006 because we took into account the period after adapting International Financial Reporting Standards (IFRS). The descriptive analysis presented in Table 1 provides information regarding the number of industries and number of firms in each industry in the total sample.

\subsection{Study variables}

This study adopts CCC as a measure of WCM. The CCC, which is an independent variable in this study, is measured as "Receivable collection period + Inventory conversion period - Payable deferral period". In this case, the CCC is calculated as "[inventory $\times 365] /$ sales + + [accounts receivable $\times 365] /$ sales - [accounts payable×365]/sales" (see Kamath, 1989; Eljelly, 2004; Charitou et al., 2010; Sharma and Kumar, 2011; Enqvist et al., 2014). Consistent with the previous studies (e.g. Jose et al., 1996; Wang, 2002; Garcia-Teurel and Martinez-Solano, 2007; Yazdanfar and Öhman, 2014; Engvist et al., 2014), the current study uses ROA as a proxy for firm profitability. Firm size is used as the moderator variable in this study and it is measured as natural Logarithm of Total Assets (LTA) according to previous studies (e.g. Al-Najjar, 2015; Castro et al., 2015; Ukaegbu, 2014; Pattitoni 
et al., 2014; Mun and Jang, 2015). In addition, Sales Growth (SG), Leverage (LEV), annual GDP (Gross Domestic Product) growth rate, and annual inflation rate are used as control variables as specified in the previous studies investigating WCM-profitability relationship (e.g. Mun and Jung, 2015).

Table 1 | Descriptive Information Regarding Sample Data

\begin{tabular}{|l|c|c|c|c|c|}
\hline Industry & TNIL & NIS & PSZP & PSZTS & NOP \\
\hline Alternative Energy & 24 & 14 & 58 & 5 & 112 \\
\hline Auto & 20 & 11 & 55 & 4 & 88 \\
\hline Beverages & 19 & 11 & 58 & 4 & 88 \\
\hline Chemicals & 31 & 24 & 77 & 8 & 192 \\
\hline Construction and materials & 30 & 16 & 53 & 6 & 128 \\
\hline Electronic & 35 & 26 & 74 & 9 & 208 \\
\hline Household & 23 & 15 & 65 & 5 & 120 \\
\hline Industrial engineering & 56 & 38 & 68 & 13 & 304 \\
\hline Leisure goods & 11 & 4 & 36 & 1 & 32 \\
\hline Personal goods & 32 & 13 & 41 & 5 & 104 \\
\hline Hardware & 28 & 24 & 86 & 8 & 192 \\
\hline Industrial transportation & 15 & 12 & 80 & 4 & 96 \\
\hline Industrial metals and mining & 6 & 4 & 67 & 1 & 32 \\
\hline Oil and gas & 4 & 1 & 25 & 0 & 8 \\
\hline Pharma & 29 & 10 & 35 & 4 & 80 \\
\hline Software & 95 & 60 & 63 & 21 & 480 \\
\hline Aerospace and defense & 3 & 2 & 67 & 1 & 16 \\
\hline Total & 285 & 62 & 100 & 2,280 \\
\hline
\end{tabular}

Note: the following abbreviation (TNIL), (NIS), (PSZP), (PSZTS) and (NOP) stand for total number of each Industry listed in Germany Stock exchange, Number of industries in sample, Percentage of sample size in a population, Percentage of sample size in total sample and Number of observations in Panel respectively Source: Authors.

On the other hand, according to Jose et al. (1996), a relationship between working capital and profitability can be affected by industry characteristics such as production process and capital intensity. Thus, in order to analyswe the industrial differences included in the sample, industry dummies are used. In this regard, 17 dummies as $(0,1)$ are added to the dataset because there are 17 different industries in the sample. 


\subsection{Data analysis}

In this study, descriptive statistics is first calculated for the variables. In order to test the correlation among the study variables, the correlation analysis is then used. We utilize three different panel data techniques to increase the consistency and efficiency of the results. In this regard, pooled OLS, fixed effects, and random effects are used to investigate the moderating impact of firm size on the relationship between CCC and ROA. We reported the results of the three methods since each of them has its strengths and weaknesses. Several authors have reported the results from the three techniques (Pollin and Zhu, 2006; Taş et al., 2013). Nonetheless, the results of the methods are same (that is neither of the methods changes the main findings of the paper). Hausman (1978) and Bruesch Pagan LM (Breusch and Pagan, 1980) tests are also carried out to choose the best model out of the three techniques for this study. Furthermore, to control endogeneity problem, Arellano-Bond's (1991) two-step Generalized Method of Moments (GMM) approach is used (Arellano and Bond, 1991). In order to test for autocorrelation for GMM, Arellano-Bond for zero autocorrelation in first differenced-errors is also conducted (Windmeijer, 2005). The results revealed no autocorrelation. The specific form that we have used for performing several regressions (based on fixed effect) is given below:

Model 1

$$
R O A=\alpha_{i}+\beta_{1} S G_{i t}+\beta_{2} L E V_{i t}+\beta_{3} G D P_{i t}+\beta_{4} I N F_{i t}+\varepsilon_{i t}
$$

Model 2

$$
R O A=\alpha_{i}+\beta_{1} S G_{i t}+\beta_{2} L E V_{i t}+\beta_{3} G D P_{i t}+\beta_{4} I N F_{i t}+\beta_{5} C C C_{i t}+\varepsilon_{i t}
$$

Model 3

$$
R O A=\alpha_{i}+\beta_{1} S G_{i t}+\beta_{2} L E V_{i t}+\beta_{3} G D P_{i t}+\beta_{4} I N F_{i t}+\beta_{5} C C C_{i t}+\beta_{6} S I Z E_{i t}+\varepsilon_{i t}
$$

Model 4

$$
\begin{aligned}
R O A=\alpha_{i} & +\beta_{1} S G_{i t}+\beta_{2} L E V_{i t}+\beta_{3} G D P_{i t}+\beta_{4} I N F_{i t}+\beta_{5} C C C_{i t}+\beta_{6} S I Z E_{i t} \\
& +\beta_{7}\left(C C C^{*} S I Z E\right)_{i t}+\varepsilon_{i t}
\end{aligned}
$$

where

$i=1, \ldots, n$ ( $n-$ the number of companies),

$t=1, \ldots, T(T-$ the number of periods $)$,

$\alpha_{\mathrm{i}}$ is fixed effect parameter that is allowed to vary across individual companies but does not vary over time. Whereas, under random effect all companies have a common mean value for the intercept,

$\varepsilon_{i t}=$ error term for each observation normally distributed with ' 0 ' mean and constant variance. However, under the Random effects model the error term $\varepsilon_{i t}$ has two components $\varepsilon_{i t}=\left(\mu_{i}+\omega_{i t}\right)$. The first component $\left(\mu_{i}\right)$ is the time - invariant individual effect that is also uncorrelated with the independent variable. The second component $\left(\omega_{i t}\right)$ which is individual time - varying across individuals and over time. Lastly, the independent variable is represented by ROA. In addition, SG, LEV, GDP and INF (inflation) are the four controlling variables. 


\section{Empirical Results}

Table 2 presents descriptive statistics and correlations for German non-financial firms. Considering the correlations among the variables, it is observed that ROA is positively correlated with LTA and negatively correlated with LEV. Both CCC and leverage are negatively correlated with ROA. The CCC and leverage are also not correlated. On the other hand, variance inflation factor is computed to check for multicollinearity among independent variables. Accordingly, the results in Table 2 reveal that all independent variable variances are below five (5) that demonstrates there is no multicollinearity in the model (see Studenmund, 1997).

Table 2 | Means, Standard Deviations and Correlations

\begin{tabular}{|l|r|c|c|c|c|c|c|c|c|}
\hline & Means & SD & VIF & CCC & SG & LTA & LEV & ROA & GDP \\
\hline CCC & 102.247 & 99.969 & 1.022 & - & - & - & - & - & - \\
\hline SG & 2.518 & 61.816 & 1.004 & -0.039 & - & - & - & - & - \\
\hline LTA & 12.020 & 2.242 & 1.016 & $0.049^{* *}$ & -0.022 & - & - & - & - \\
\hline LEV & 0.537 & 0.267 & 1.031 & $-0.125^{* * *}$ & -0.027 & $0.107^{* * *}$ & - & - & - \\
\hline ROA & 0.011 & 0.271 & - & -0.026 & 0.012 & $0.133^{* * *}$ & $-0.175^{* * *}$ & - & - \\
\hline GDP & 1.319 & 3.025 & 1.473 & -0.004 & 0.028 & -0.003 & -0.031 & $0.081^{* * *}$ & - \\
\hline INF & 1.689 & 0.688 & 1.471 & -0.010 & 0.002 & 0.006 & -0.014 & 0.012 & $0.566^{* * *}$ \\
\hline
\end{tabular}

Note: CCC represents the cash conversion cycle; SG the sales growth; LTA is logarithm of total asset; LEV the leverage; ROA the return on asset; GDP the annual gross domestic product growth rate; INF the annual inflation rate.

*** Represents significance at $1 \%$ level. ${ }^{* *}$ Represents significance at $5 \%$ level.

Source: Authors.

In Table 3 (Panels A-C) there is presented the moderating impact of firm size on the relationship between CCC and ROA using four methods (Fixed in Panel A, Random in Panel B, OLS in Panel C, and GMM in Panel D). In this regard, first, four control variables SG, LEV, GDP, and INF are investigated, and the results of the methods show strong association of firm performance with LEV, GDP, and INF. The results also show LEV and INF have statistically significant negative association with ROA. Particularly, coefficients for leverage $(-0.26969$ under Fixed Effects in Panel A, -0.198846 under Random Effects in Panel B, -0.175134 under OLS in Panel C, and -1.124223 under GMM in Panel D) and coefficients for INF $(-0.01914$ under Fixed Effects in Panel A, -0.019284 under Random Effects in Panel B, -0.019332 under OLS in Panel C, and -0.0050213 under GMM in Panel D) are all highly statistically significant at 5 per cent or better using each method. The GDP, on the other hand, has a positive impact on ROA. The coefficients for GDP $(0.00896$ under Fixed Effects in Panel A, 0.0091912 under Random Effects in Panel B, 0.009265 under OLS in Panel C, and 0.0018723 under GMM in Panel D) are also highly statistically significant under all methods. The SG, however, does not show any statistically impact on ROA. 
Table 3 | The Moderating Role of Firm Size

\begin{tabular}{|c|c|c|c|c|}
\hline \multicolumn{5}{|c|}{ Panel A: Fixed Effects } \\
\hline & Model 1 & Model 2 & Model 3 & Model 4 \\
\hline Intercept & $0.176630^{* * *}$ & 0.203753 & -0.186975 & -0.042700 \\
\hline Sale growth & 0.000040 & 0.000035 & 0.000041 & 0.000039 \\
\hline Leverage & $-0.269690^{* * *}$ & $-0.277952 * * *$ & $-0.264565^{* * *}$ & $-0.269184^{* * *}$ \\
\hline GDP & $0.008960 * * *$ & $0.008962 * * *$ & $0.009212^{* * *}$ & $0.009286^{* * *}$ \\
\hline Inflation & $-0.019140^{* *}$ & $-0.019457^{* *}$ & $-0.020607^{* *}$ & $-0.021224^{* *}$ \\
\hline CCC & - & $-0.000216^{* *}$ & $-0.000222^{* *}$ & $-0.001355^{* * *}$ \\
\hline LTA & - & - & $0.032089 * *$ & 0.018997 \\
\hline LTA $\times$ CCC & - & - & - & $0.000107 * *$ \\
\hline F-statistic & $21.15^{* * *}$ & $18.06^{* * *}$ & $15.77^{* * *}$ & $14.42^{* * *}$ \\
\hline \multicolumn{5}{|c|}{ Panel B: Random Effects } \\
\hline & Model 1 & Model 2 & Model 3 & Model 4 \\
\hline Intercept & $0.138543 * * *$ & $0.158455^{* * *}$ & $-0.069803^{*}$ & 0.004237 \\
\hline Sale growth & 0.000030 & 0.000022 & 0.000031 & 0.000029 \\
\hline Leverage & $-0.198846^{* * *}$ & $-0.205860^{* * *}$ & $-0.215261^{* * *}$ & $-0.216586^{* * *}$ \\
\hline GDP & $0.009191 * * *$ & $0.009184^{* * *}$ & $0.009282 * * *$ & $0.009360 * * *$ \\
\hline Inflation & $-0.019284^{* *}$ & $-0.0195058^{* *}$ & $-0.020200^{* *}$ & $-0.020795^{* *}$ \\
\hline CCC & - & $-0.000154^{* *}$ & $-0.000173^{* * *}$ & $-0.001010^{* * *}$ \\
\hline LTA & - & - & $0.019657^{* * *}$ & $0.013080^{* * * *}$ \\
\hline LTA $\times$ CCC & - & - & - & $0.000074^{* *}$ \\
\hline Wald chi2 & $90.02 * * *$ & $95.80 * * *$ & $136.35 * * *$ & $142.98 * * *$ \\
\hline \multicolumn{5}{|c|}{ Panel C: OLS } \\
\hline & Model 1 & Model 2 & Model 3 & Model 4 \\
\hline Intercept & $0.125790 * * *$ & $0.142953 * * *$ & $-0.073202^{* *}$ & -0.007250 \\
\hline Sale growth & 0.000025 & 0.000016 & 0.000030 & 0.000026 \\
\hline Leverage & $-0.175134^{* * *}$ & $-0.181371^{* * *}$ & $-0.199712^{* * *}$ & $-0.200756^{* * *}$ \\
\hline GDP & $0.009265^{* * *}$ & $0.009260 * * *$ & $0.009326^{* * *}$ & $0.009397^{* * *}$ \\
\hline Inflation & $-0.019332^{* *}$ & $-0.019520^{* *}$ & $-0.020190 * *$ & $-0.020737^{* *}$ \\
\hline $\mathrm{CCC}$ & - & $-0.000132 * *$ & $-0.000158^{* * *}$ & $-0.000910 * * *$ \\
\hline LTA & - & - & $0.019116^{* * *}$ & $0.013353 * * *$ \\
\hline LTA $\times$ CCC & - & - & - & $0.000066^{* *}$ \\
\hline F-statistic & $22.54 * * *$ & $19.17^{* * *}$ & $26.35^{* * *}$ & $23.54 * * *$ \\
\hline \multicolumn{5}{|c|}{ Panel D: GMM } \\
\hline & Model 1 & Model 2 & Model 3 & Model 4 \\
\hline Intercept & $0.125795^{* * *}$ & $0.142954^{* * *}$ & -0.073202 & -0.007250 \\
\hline Sale growth & $0.000025 * * *$ & $0.000016 * *$ & $0.000028^{* * *}$ & $0.000026^{* * *}$ \\
\hline Leverage & $-0.175134^{* * *}$ & $-0.181371 * * *$ & $-0.199713^{* * *}$ & $-0.200756 * * *$ \\
\hline GDP & $0.009266^{* * *}$ & $0.009260^{* * *}$ & $0.009326^{* * *}$ & $0.009397^{* * *}$ \\
\hline Inflation & -0.019333 & -0.019520 & -0.020190 & -0.020737 \\
\hline $\mathrm{CCC}$ & - & $-0.000132^{* *}$ & $-0.000159 * * *$ & $-0.000910 * *$ \\
\hline LTA & - & - & $0.019116^{* * *}$ & $0.013353^{* * * *}$ \\
\hline LTA $\times$ CCC & - & - & - & $0.000066^{* *}$ \\
\hline Wald chi2 & 169.40 & 223.10 & 220.00 & 178.10 \\
\hline \multicolumn{5}{|l|}{ Arellano-Bond test: } \\
\hline Arellano-Bond test lag 1 & $2.7750[0.006]$ & $2.7880[0.005]$ & $2.9750[0.003]$ & $3.0150[0.003]$ \\
\hline Arellano-Bond test lag 2 & $0.8547[0.393]$ & $0.8395[0.401]$ & $0.7030[0.482]$ & $0.6726[0.501]$ \\
\hline
\end{tabular}

Note: CCC represents the cash conversion cycle; SG the sales growth; LTA is logarithm of total asset; LEV the leverage; ROA the return on asset; GDP the annual gross domestic product growth rate; INF the annual inflation rate.

${ }^{* * * * * *}$, and ${ }^{*}$ donate statistical significance at $1 \%, 5 \%$, and $10 \%$ respectively.

Source: Authors. 
Table 4 | Impact of Industry Dummies

\begin{tabular}{|c|c|c|c|}
\hline & OLS & Random Effects & GMM \\
\hline SG & 0.000014 & 0.000021 & 0.000014 \\
\hline LEV & $-0.206801^{* * *}$ & $-0.219548^{* * *}$ & $-0.206801^{* * *}$ \\
\hline GDP & $0.009422^{* * *}$ & $0.009385^{* * *}$ & $0.009422^{* * *}$ \\
\hline INF & $-0.020990^{* *}$ & $-0.020997^{* *}$ & -0.020990 \\
\hline $\mathrm{CCC}$ & $-0.001146^{* * *}$ & $-0.001181^{* * *}$ & $-0.001146^{* *}$ \\
\hline LTA & $0.014133^{* * *}$ & $0.014135^{* * *}$ & $0.014133^{* * *}$ \\
\hline CCCXLTA & $0.000084^{* * *}$ & $0.000088^{* * *}$ & $0.000084^{* * *}$ \\
\hline Dummy 1 & -0.032445 & -0.035874 & -0.032440 \\
\hline Dummy 2 & 0.039339 & 0.036677 & 0.039339 \\
\hline Dummy 3 & 0.101489 & 0.101290 & $0.101489^{* * *}$ \\
\hline Dummy 4 & 0.017435 & 0.015927 & 0.017435 \\
\hline Dummy 5 & 0.129393 & 0.126706 & $0.129393^{* *}$ \\
\hline Dummy 6 & 0.126835 & 0.123823 & $0.126835^{* * *}$ \\
\hline Dummy 7 & 0.097586 & 0.096271 & $0.097586^{* * *}$ \\
\hline Dummy 8 & 0.082282 & 0.079630 & $0.082282^{* * *}$ \\
\hline Dummy 9 & 0.077729 & 0.076238 & $0.077729 * *$ \\
\hline Dummy 10 & 0.107874 & 0.104863 & $0.107874^{* * *}$ \\
\hline Dummy 11 & 0.066072 & 0.062930 & $0.066072^{* * *}$ \\
\hline Dummy 12 & 0.069392 & 0.068632 & $0.069392^{* * *}$ \\
\hline Dummy 13 & 0.058101 & 0.054405 & $0.058101^{* *}$ \\
\hline Dummy 15 & -0.039242 & -0.043223 & -0.039240 \\
\hline Dummy 16 & 0.069418 & 0.066586 & $0.069418^{* * *}$ \\
\hline Dummy 17 & 0.122137 & 0.121886 & $0.122137^{* * *}$ \\
\hline \multirow[t]{2}{*}{ Intercept } & -0.081519 & -0.073012 & -0.081520 \\
\hline & $\mathrm{F}=10.05^{* * *}$ & Wald Chi2 $=187.54$ & Wald (joint) $=2,712^{* * *}$ \\
\hline $\begin{array}{l}\text { Joint test for } \\
\text { dummies }\end{array}$ & $F(16 ; 2,256)=3.93 * * *$ & $\operatorname{chi} 2(16)=40.67^{* * *}$ & - \\
\hline \multicolumn{4}{|c|}{ Arellano-Bond test: } \\
\hline $\begin{array}{l}\text { Arellano-Bond } \\
\text { test lag } 1\end{array}$ & - & - & $2.5880^{* *}$ \\
\hline $\begin{array}{l}\text { Arellano-Bond } \\
\text { test lag } 2\end{array}$ & - & - & 0.3432 \\
\hline
\end{tabular}

Note: CCC represents the cash conversion cycle; SG the sales growth; LTA is logarithm of total asset; LEV the leverage; ROA the return on asset; GDP the annual gross domestic product growth rate; INF the annual inflation rate. Joint test for dummies under OLS and Random Model reject the Null Hypothesis that dummies are equal to zero.

$* * * * *$, and ${ }^{*}$ donate statistical significance at $1 \%, 5 \%$, and $10 \%$ respectively.

Source: Authors. 
After the control variables, the CCC is included into the model, and the coefficients $(-0.0002163$ in Panel A, -0.000154 in Panel B, -0.0001317 in Panel C, and -0.0002163 in Panel D) that are computed are highly statistically significant at 5 per cent or better under each method. After confirming the fit of Model 2, firm size is included in the following model which is Model 3, and its estimated coefficients (0.032089 in panel A, 0.0196567 in panel B and 0.0191163 in panel C) are all highly statistically significant at 5 per cent or better. Finally, in Model 4, the interaction between CCC and firm size is incorporated, and the estimated coefficients ( 0.000106 in panel A, 0.0000744 in panel B and 0.0000658 in panel C) are highly statistically significant at 5 per cent or better. Consequently, the computed F-statistics (in panel A and C) and Wald Chi2 (in panel B) are all highly significant meaning that all the model $(1-4)$ are non-zero and selected control variables are appropriate. Hausman test is also applied to check which model is more suitable, and the result (chi2 $=6.69$; prob $>$ chi2 $=0.4617$ ) shows that random effects model is appropriate (see Baltagi, 2005). In addition, Bruesch Pagan LM test is applied to make comparison between random effects and OLS (Breusch and Pagan, 1980). Accordingly, the results (Chibar2 $(01)=66.59$; prob $>$ Chibar2 $=0.000)$ reveal that random effect model is better.

In addition to Fixed Effects, Random Effects, and OLS, we utilize the GMM method to have greater control of endogeneity and multicollinearity of independent variables (Arellano and Bond, 1991). As can be seen in Panel D in Table 3, the GMM method produces similar results found under the other methods. In addition, according to Arellano-Bond statistics (AR-2, $\mathrm{z}$ value $=0.6726, \mathrm{p}<0.501)$, the null hypotheses indicating the nonexistence of firstand second-order autocorrelation is accepted. These results reveal that there is no first and second-order autocorrelation and the instrument is valid (Arellano and Bond, 1991). Based on these results, both $\mathrm{H} 1$ and $\mathrm{H} 2$ are supported.

In order to test the industry effects on the moderating role of firm size on CCC-ROA relationship, we integrated industry dummies into the analyses under the methods (OLS, Fixed Effects, Random Effects, and GMM). However, dummies are not tested with fixed effects because in fixed effect model the variables that are not time varying such as industry dummies cannot be tested (Wooldridge, 2006). As we can see in Table 4, after the integration of industry dummies into the analyses, the interaction effect of CCC and firm size on ROA continues to be significant under all of the methods. In addition to this, the statistically significant negative relationship between CCC and ROA continues to exist. These results imply that industrial differences do not influence the moderating role of firm size on CCC-ROA relationship.

Figure 2 shows the ROA changes for small, medium-sized, and large firms as the length of CCC varies. As can be seen in Figure 2, the ROA is better for large firms compared with the small and medium-sized ones. Among small firms, as CCC gets longer, the ROA gets worse. This is also the case in medium-sized firms even though the rate of decline in profitability is not as large as it is in small firms. For the large firms, on the other hand, the ROA becomes better as the CCC gets longer. 


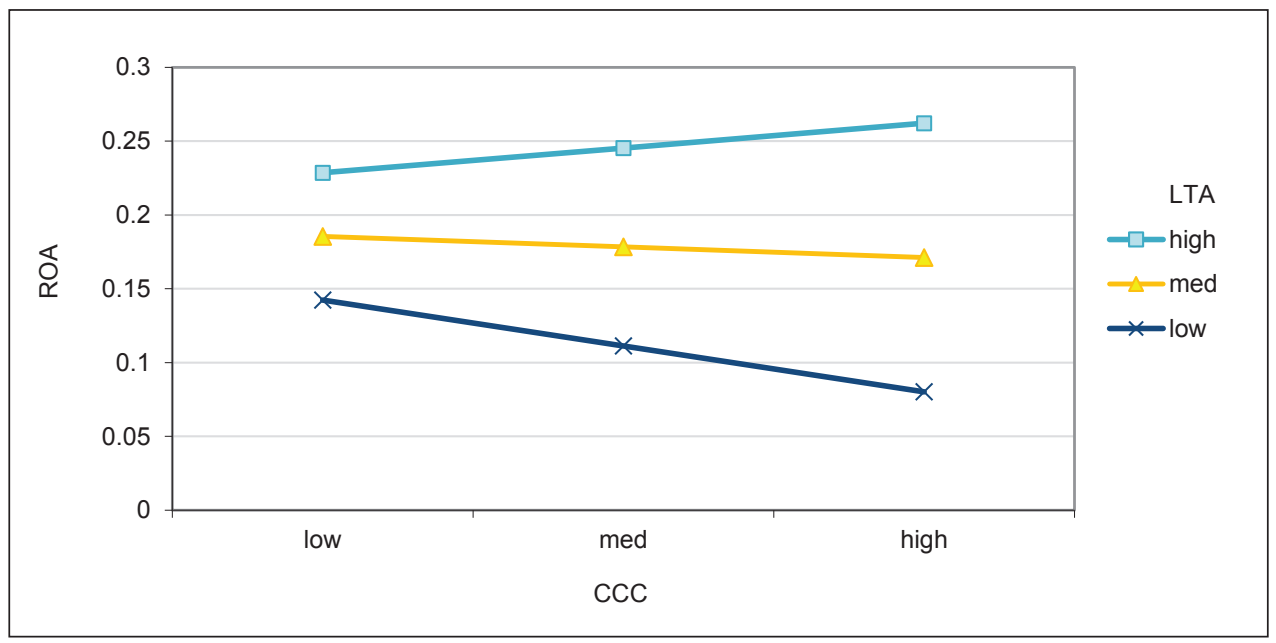

Note: CCC represents the cash conversion cycle; LTA is logarithm of total asset; ROA the return on asset. Source: Authors.

To sum up, the current study may identify the reason behind inconclusive results of the previous studies because it demonstrates that firm size has a moderating role in the relationship between CCC and profitability.

\section{Conclusions and Implications}

The current study investigated whether firm size moderates the relationship between CCC, which is a measure of WCM, and ROA. Accordingly, the results have proved the moderating role of firm size on the relationship between $\mathrm{CCC}$ and profitability for the German non-financial firms regardless of the industry in which they operate. In this regard, the results have revealed that as the firm size gets smaller, the negative impact of CCC on ROA becomes stronger for the firms. It is a well-known fact that a move towards a longer CCC results in holding more inventories and receivables which necessitate a greater need for expensive external financing (Richards and Laughlin, 1980). In this regard, this finding of the current study can be supported by the notion that outside financing is difficult and expensive to obtain for small firms, which are more financially constrained. In addition, small firms encounter higher information asymmetry and agency costs (for example, Almeida et al., 2004; Carpenter et al., 1994; Faulkender and Wang, 2006; Stiglitz and Weiss, 1981; Rajan and Zingales, 1995; Berger and Udell, 1995; Shane and Cable, 2002; Cassar, 2004). This finding is also supported by the prior studies which have revealed that small firms have stronger relationship between WCM and profitability since they have only limited access to sources (Moss and Stine, 1993). In this context, the other finding of the current study has shown that the negative impact of CCC on ROA of the medium-sized firms is not as sharp as it is for the small ones. Further, the last finding of the current study has disclosed that 
as the firm size gets bigger and the CCC gets longer, the ROA does not decrease but increases. This finding indicates that profitable large firms have long CCCs. This might have resulted from the fact that larger firms, contrary to smaller ones, can more easily finance increasing working capital at low cost and they invest more in working capital by lengthening CCC. This can also be supported by the assertion of Baños-Caballero et al., (2010) which implies that companies having greater internal financing opportunity and better access to resources have a higher level of working capital.

Consequently, several implications can be derived from the findings of this study. First, the findings imply that effective WCM has a significant effect especially on the profitability of small and medium-sized firms operating in different industries. Thus, managers of small and medium-sized German non-financial companies and others operating in similar contexts should strive to i) delay the payment for payables to vendors, ii) turn over inventories quickly, and iii) speed up collections of account receivables to reduce the cash kept in working capital to increase profitability and competitiveness. In this regard, managers should tailor appropriate strategies. For example, they can offer discounts to the debtors for their early payments. However, the findings suggest that WCM strategies of medium-sized firms do not need to be as aggressive as the ones implemented by the small firms.

Second, managers of large German non-financial firms and others operating in similar contexts can ease the CCC by offering generous credit policies to their clients, making investment in inventories, and paying trade payables more quickly which in turn lead improvements in profitability by: (1) encouraging customers to buy goods when demand is low and increasing firms' sales, (2) reducing supply costs and the risk of interruptions during delivery, (3) preventing lost sales and additional production costs, (4) getting important discounts when paying for accounts payable earlier (Emery, 1987; Petersen and Rajan, 1997; Schiff and Lieber, 1974; Blinder and Maccini, 1991; Wilner, 2000). However, managers of these firms should keep in mind that lengthening CCC excessively might have an adverse impact on profitability starting from a particular level due to excessive cost of borrowing, inventory maintenance such as rent and insurance, as well as financial resources tied up in unprofitable areas (Baños-Caballero et al., 2014).

To sum up, firm size has a moderating effect on the relationship between CCC and profitability. The main implication that can be drawn from this finding is that managers, who make strategic decisions especially regarding the working capital management, should first consider the size of their firms because, due to the firm size effect, successful strategies determined and applied by large firms may not be appropriate for small and medium-sized ones.

The results and implications of the current study should be interpreted in light of the following limitations. First of all, this study is conducted in a single country. Second, it focuses only on non-financial firms. Third, the sample size is low. Therefore, the future studies should investigate the moderating role of firm size in CCC-ROA relationship in other countries as well as in Germany by using larger samples to provide comparable results to the ones found in the current study. 


\section{References}

Almeida, H., Campello, M., Weisbach, M. S. (2004). The Cash Flow Sensitivity of Cash. Journal of Finance, 59(4), 1777-1804, https://doi.org/10.1111/j.1540-6261.2004.00679.x

Al-Najjar, B. (2015). The Effect of Governance Mechanisms on Small and Medium-Sized Enterprise Cash Holdings: Evidence from the United Kingdom. Journal of Small Business Management, 53(2), 303-320, https://doi.org/10.1111/jsbm.12062

Aregbeyen, O. (2013). The Effects of Working Capital Management on the Profitability of Nigerian Manufacturing Firms. Journal of Business Economics and Management, 14(3), 520-534, https://doi.org/10.3846/16111699.2011.651626

Arellano, M., Bond, S. (1991). Some Tests of Specification for Panel Data: Monte Carlo

Evidence and an Application to Employment Equations. The Review of Economic Studies, 58(2), 277-297, https://doi.org/10.2307/2297968

Baltagi, B. H. (2005). Econometric Analysis of Panel Data. Third Edition, John Wiley\&Sons Inc.

Baños-Caballero, S., Garcia-Teruel, P. J., Martinez-Solano, P. (2010). Working Capital Management in SMEs. Accounting and Finance, 50(3), 511-527, https://doi. org/10.1111/j.1467-629x.2009.00331.x

Baños-Caballero, S., García-Teruel, P. J., Martínez-Solano, P. (2014). Working Capital Management, Corporate Performance, and Financial Constraints. Journal of Business Research, 67(3), 332-338. https://doi.org/10.1016/j.jbusres.2013.01.016

Berger, A., Udell, G. (1995). Relationship Lending and Lines of Credit in Small Firm Finance. Journal of Business, 68(3), 351-382. https://doi.org/10.1086/296668

Blinder, A. S., Maccini, L. J. (1991). Taking Stock: A Critical Assessment of Recent Research on Inventories. Journal of Economic Perspectives, 5(1), 73-96, https://doi.org/10.1257/ jep.5.1.73

Breusch, T. S., Pagan, A. R. (1980). The Lagrange Multiplier Test and Its Applications to Model Specification in Econometrics. Review of Economic Studies, 47(1), 239-253, https://doi.org/10.2307/2297111

Carpenter, R. E., Fazzari, S. M., Petersen, B. C. (1994). Inventory Investment, Internal Finance Fluctuations and Business Cycle. Brooking Papers on Economic Activity, 25(2), 75-135, https://doi.org/10.2307/2534655

Cassar, G. (2004). The Financing of Business Start-Ups. Journal of Business Venturing, 19(2), 261-283, https://doi.org/10.1016/s0883-9026(03)00029-6

Castro, P., Tascón, M. T., Amor-Tapia, B. (2015). Dynamic Analysis of the Capital Structure in Technological Firms Based on Their Life Cycle Stages. Spanish Journal of Finance and Accounting, 44(4), 458-486, https://doi.org/10.1080/02102412.2015.108820

Charitou, M. S., Elfani, M., Lois, P. (2010). The Effect of Working Capital Management on Firm's Profitability: Empirical Evidence from an Emerging Market. Journal of Business and Economics Research, 8(12), 63-68, https://doi.org/10.19030/jber.v8i12.782

Deloof, M. (2003). Does Working Capital Management Affect Profitability of Belgian Firms? Journal of Business Finance and Accounting, 30(3), 573-587, https://doi. org/10.1111/1468-5957.00008

Dong, H. P., Su, J. T. (2010). The Relationship between Working Capital Management and Profitability: A Vietnam Case. International Research Journal of Finance and Economics, 49, 59-67. 
Ebben, J. J., Johnson, A. C. (2011). Cash Conversion Cycle Management in Small Firms: Relationships with Liquidity, Invested Capital, and Firm Performance. Journal of Small Business and Entrepreneurship, 24(3), 381-396, https://doi.org/10.1080/08276331.2011.10593545

Eljelly, A. M. A. (2004). Liquidity-profitability Trade-Off: An Empirical Investigation in an Emerging Market. International Journal of Commerce and Management, 14(2), 48-61, https://doi.org/10.1108/10569210480000179

Emery, G. W. (1984). A Pure Financial Explanation for Trade Credit. Journal of Financial and Quantitative Analysis, 9(3), 271-285, https://doi.org/10.2307/2331090

Emery, G. W. (1987). An Optimal Financial Response to Variable Demand. Journal of Financial and Quantitative Analysis, 22(2), 209-225, https://doi.org/10.2307/2330713

Enqvist, J., Graham, M., Nikkinen, J. (2014). The Impact of Working Capital Management on Firm Profitability in Different Business Cycles: Evidence from Finland. Research in International Business and Finance, 32, 36-49, https://doi.org/10.1016/j.ribaf.2014.03.005

Faulkender, M. W., Wang, R. (2006). Corporate Financial Policy and the Value of Cash. Journal of Finance, 61(4), 1957-1990, https://doi.org/10.1111/j.1540-6261.2006.00894.x

Filbeck, G., Krueger, T., Preece, D. C. (2007). CFO Magazine's Working Capital Survey: Do Selected Firms Work for Shareholders? Quarterly Journal of Business and Economics, 46(2), 3-22, https://doi.org/10.3905/joi.2003.319560

Garcia-Teurel, P. J., Martinez-Solano, P. (2007). Effects of Working Capital Management on SME Profitability. International Journal of Managerial Finance, 3(2), 164-177, https://doi.org/10.1108/17439130710738718

Gill, A., Biger, N., Mathur, N. (2010). The Relationship between Working Capital Management and Profitability: Evidence from the United States. Business and Economics Journal, 10(1), 1-9, https://doi.org/10.9734/bjemt/2014/5427

Gitman, L. J. (1974). Estimated Corporate Liquidity Requirements: a Simplified Approach. The Financial Review, 9(1), 79-88, https://doi.org/10.1111/j.1540-6288.1974.tb01453.x

Hager, H. C. (1976). Cash Management and the Cash Cycle. Management Accounting, 57(9), 19-21.

Hausman, J. (1978). Specification Tests in Econometrics. Econometrica, 46(6), 1251-1271, https://doi.org/10.2307/1913827

Hutchison P. D., Farris, M. T., Anders, S. B. (2007). Cash-to-Cash Analysis and Management. CPA Journal, 77(8), 42-47.

Jose, M., Lancaster, C., Stevens, J. L. (1996). Corporate Returns and Cash Conversion Cycles. Journal of Economics and Finance, 20(1), 33-46, https://doi.org/10.1007/bf02920497

Kamath, R. (1989). How Useful Are Common Liquidity Measures? Journal of Cash Management, 9(1), 24-28.

Lind, L., Pirttilä, M., Viskari, S., Schupp, F., Kärri, T. (2012). Working Capital Management in the Automotive Industry: Financial Value Chain Analysis. Journal of Purchasing and Supply Management, 18(2), 92-100, https://doi.org/10.1016/j.pursup.2012.04.003

Long, M. S., Malitz, I. B., Ravid, S. A. (1993). Trade Credit, Quality Guarantees, and Product Marketability. Financial Management, 22(4), 117-127, https://doi.org/10.2307/3665582

Lyroudi, K., Lazaridis, J. (2000). The Cash Conversion Cycle and Liquidity Analysis of the Food Industry in Greece. Working Paper, Social Science Research Network Paper Collection, https://doi.org/10.2139/ssrn.236175. Retrieved from: http://papers.ssrn.com

Moss, J. D., Stine, B. (1993). Cash Conversion Cycle and Firm Size: a Study of Retail Firms. Managerial Finance, 19(8), 25-34, https://doi.org/10.1108/eb013739 
Mun, S. G., Jang, S. (2015). Working Capital, Cash Holding, and Profitability of Restaurant Firms. International Journal of Hospitality Management, 48, 1-11, https://doi.org/10.1016/j. ijhm.2015.04.003

Nobanee, H., Abdullatif, M., Al Hajjar, M. (2011). Cash Conversion Cycle and Firm's Performance of Japanese Firms. Asian Review of Accounting, 19(2), 147-156, https://doi.org/10.1108/13217341111181078

Padachi, K. (2006). Trends in Working Capital Management and Its Impact on Firms' Performance: an Analysis of Mauritian Small Manufacturing Firms. International Review of Business Research Papers, 2(2), 45-58.

Pattitoni, P., Petracci, B., Spisni, M. (2014). Determinants of Profitability in the EU-15 Area. Applied Financial Economics, 24(11), 763-775, https://doi.org/10.1080/09603107.2014.90 4488

Petersen, M. A., Rajan, R. G. (1997). Trade Credit: Theories and Evidence. Review of Financial Studies, 10(3), 661-691, https://doi.org/10.1093/rfs/10.3.661

Pollin, R., Zhu, A. (2006). Inflation and Economic Growth: a Cross-Country Nonlinear Analysis. Journal of Post Keynesian Economics, 28(4), 593-614, https://doi.org/10.2753/ pke0160-3477280404

Rajan, R. G., Zingales, L. (1995). What Do We Know about Capital Structure? Some Evidence from International Data. The Journal of Finance, 50(5), 1421-1460, https://doi. org/10.1111/j.1540-6261.1995.tb05184.x

Richards, V., Laughlin. E. (1980). A Cash Conversion Cycle Approach to Liquidity Analysis. Financial Management, 9(1), 32-38, https://doi.org/10.2307/3665310

Ruback, R. S., Sesia, A. (2003). Dell's Working Capital. Boston: Harvard Business School Press, https://doi.org/10.1287/mnsc.48.3.364.7731

Schiff, M., Lieber, Z. (1974). A Model for the Integration of Credit and Inventory Management. Journal of Finance, 29(1), 133-140, https://doi.org/10.1111/j.1540-6261.1974.tb00029.x

Shane, S. A., Cable, D. (2002). Network Ties, Reputation, and the Financing of New Ventures. Management Science, 48(3), 364-381, https://doi.org/10.1287/mnsc.48.3.364.7731

Sharma, A. K., Kumar, S. (2011). Effect of Working Capital Management on Firm Profitability, Empirical Evidence from India. Global Business Review, 12(1), 159-173, https://doi. org/10.1177/097215091001200110

Shin, H. H., Soenen, L. (1998). Efficiency of Working Capital Management and Corporate Profitability. Financial Practice and Education, 8(2), 39-45.

Singhania, M., Sharma, N., Rohit, J. Y. (2014). Working Capital Management and Profitability: Evidence from Indian Manufacturing Companies. Decision, 41(3), 313-326, https://doi.org/10.1007/s40622-014-0043-3

Smith, J. K. (1987). Trade Credit and Informational Asymmetry. Journal of Finance, 42(4), 863-872, https://doi.org/10.1111/j.1540-6261.1987.tb03916.x

Stiglitz, J. E., Weiss, A. (1981). Credit Rationing in Markets with Imperfect Information. The American Economic Review, 71(3), 393-410.

Storey, D. J. (1989). Firm Performance and Size: Explanations from the Small Firm Sectors. Small Business Economics, 1(3), 175-180, https://doi.org/10.1007/bf00401855

Studenmund, A. H. (1997). Using Econometrics, A Practical Guide. Boston: Addison-Wesley Longman. 
Taş, N., Hepşen, A., Önder, E. (2013). Analyzing Macroeconomic Indicators of Economic Growth Using Panel Data. Journal of Finance and Investment Analysis, 2(3), 41-53, https://doi. org/10.2139/ssrn.2264388

Ukaegbu, B. (2014). The Significance of Working Capital Management in Determining Firm Profitability: Evidence from Developing Economies in Africa. Research in International Business and Finance, 31, 1-16, https://doi.org/10.1016/j.ribaf.2013.11.005

Wang, Y. J. (2002). Liquidity Management, Operating Performance, and Corporate Value: Evidence from Japan and Taiwan. Journal of Multinational Financial Management, 12(2), 159-169, https://doi.org/10.1016/s1042-444x(01)00047-0

Wilner, B. (2000). The Exploitation of Relationships in Financial Distress: the Case of Trade Credit. Journal of Finance, 55(1), 153-178, https://doi.org/10.1111/0022-1082.00203

Windmeijer, F. (2005). A Finite Sample Correction for the Variance of Linear Efficient Two-Step GMM Estimators. Journal of Econometrics, 126(1), 25-51, https://doi.org/10.1016/j. jeconom.2004.02.005

Wooldridge, J. M. (2006). Introductory Econometrics: A Modern Approach. $3^{\text {rd }}$ edition, Cengage Learning. South-Western. ISBN 9780324323481.

Yazdanfar, D., Öhman, P. (2014). The Impact of Cash Conversion Cycle on Firm Profitability: An Empirical Study Based on Swedish Data. International Journal of Managerial Finance, 10(4), 442-452, https://doi.org/10.1108/ijmf-12-2013-0137 